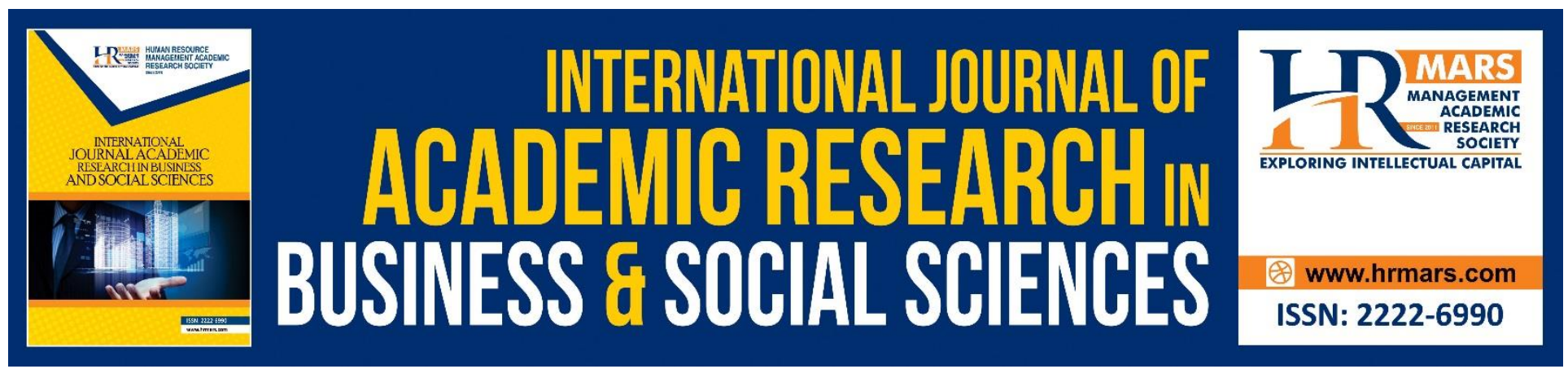

\title{
A Proposed Framework on Urban Vacationers Motivation in Visiting Spa and Wellness Centre
}

Sathish Kumar Velayuthan, Nik Alif Amri Nik Hashim, Abdullah Bin Muhamed Yusoff, Zaimatul Awang, Shah Iskandar Fahmie Bin Ramlee

To Link this Article: http://dx.doi.org/10.6007/IJARBSS/v9-i5/5912

DOI: $10.6007 /$ IJARBSS/v9-i5/5912

Received: 12 March 2019, Revised: 01 April 2019, Accepted: 21 April 2019

Published Online: 22 May 2019

In-Text Citation: (Velayuthan, Hashim, Yusoff, Awang, \& Ramlee, 2019)

To Cite this Article: Velayuthan, S. K., Hashim, N. A. A. N., Yusoff, A. B. M., Awang, Z., \& Ramlee, S. I. F. Bin. (2019). A Proposed Framework on Urban Vacationers Motivation in Visiting Spa and Wellness Centre. International Journal of Academic Research Business and Social Sciences, 9(5), 597-603.

Copyright: (C) 2019 The Author(s)

Published by Human Resource Management Academic Research Society (www.hrmars.com)

This article is published under the Creative Commons Attribution (CC BY 4.0) license. Anyone may reproduce, distribute, translate and create derivative works of this article (for both commercial and non-commercial purposes), subject to full attribution to the original publication and authors. The full terms of this license may be seen

at: http://creativecommons.org/licences/by/4.0/legalcode

Vol. 9, No. 5, 2019, Pg. 597 - 603

http://hrmars.com/index.php/pages/detail/IJARBSS

JOURNAL HOMEPAGE

Full Terms \& Conditions of access and use can be found at http://hrmars.com/index.php/pages/detail/publication-ethics 


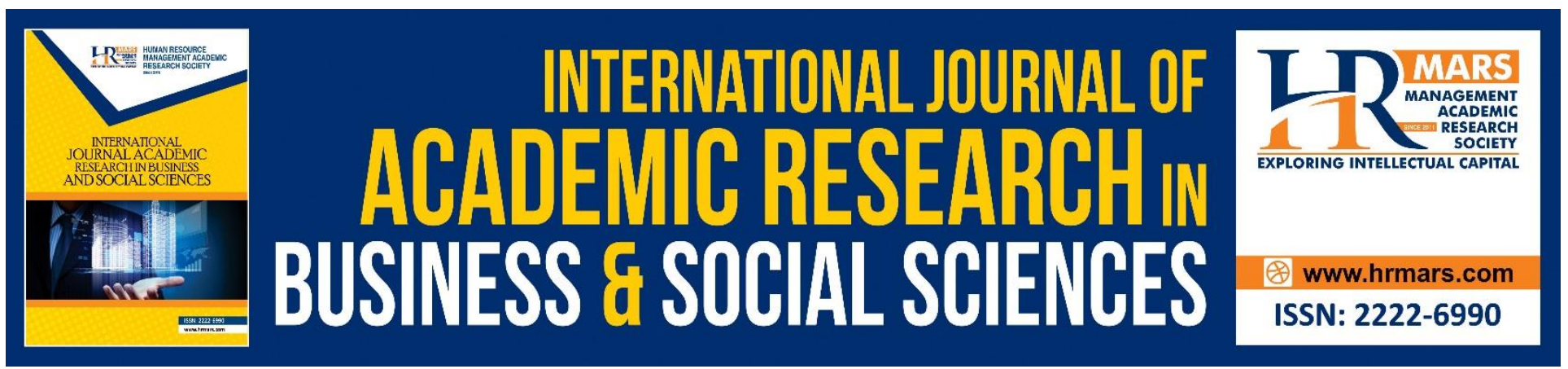

\title{
A Proposed Framework on Urban Vacationers Motivation in Visiting Spa and Wellness Centre
}

\section{Sathish Kumar Velayuthan, Nik Alif Amri Nik Hashim, Abdullah Bin Muhamed Yusoff, Zaimatul Awang}

Faculty of Hospitality, Tourism and Wellness, Universiti Malaysia Kelantan, Malaysia

\section{Shah Iskandar Fahmie Bin Ramlee}

Faculty of Entrepreneurship and Business, Universiti Malaysia Kelantan, Malaysia

\begin{abstract}
Visiting Spa and wellness tourism centre is a new social trend among wellness tourist around Malaysia. The fact shows that the number of spa and wellness centre increases from year to year and the practice towards healthier lifestyle were accepted worldwide. The individual health and wellness concern is one of the significant factors that contribute to the succession of the spa and wellness industry. This paper aimed to examine the literature on the factors influencing tourist motivation towards visiting spa and wellness tourism destinations. The literature reviews shows that there will be a positive relationship between relaxation and relief, health and beauty, escape and selfdevelopment with travel motivation among tourist. The findings of this study are expected to fill the gap in the literature by extending the knowledge of existing literature on Spa motivation and to educate the public knowledge and professional service delivery.
\end{abstract}

Keywords: Domestic Tourist, Motivation, Visitation, Spa and Wellness

\section{Introduction}

Lately, the reality shows that the quantity of the spa centre and wellness focuses on rising and practice towards a more beneficial way of life. Individual health and wellness concern is one of the central points that contribute to the triumph of this industry. These can be seen through the current action by global spa industry, who actively promotes the spa industry to next level of the relentless world with new eras of provident and more advantageous people groups. Global Spa and Wellness Summit (GSWS) has been administrating the global spa industry to improve the quality of services that involve all level of stakeholders both regional and global by discussing the present patterns and issues identified with this industry (Global Wellness Summit, 2016). 
Wellness in diversity proves that health and wellness tourism is among the oldest form of tourism that turns into a normal routine to some nowadays. Furthermore, the ancient civilisation as far back as 5000 - $10000 \mathrm{BC}$ rehearsed considerable treatments which are found in spas and wellness centres today, for example, Ayurveda, Chinese prescriptions and Thai massage (Smith, Macleod \& Robertson, 2010). Correspondingly, now it has turned into a social pattern among Malaysian urban vacationers to visit spa and wellness centres to rejuvenate themselves and such succession is a vow by Malaysian Association of Wellness and Spa (MAWSPA) which has been formed to be the voice of the Malaysian Spa industry to educate the public knowledge and professional service delivery. Hence, this paper aims to review the literature on the factors influencing tourist motivation towards visiting spa and wellness as tourism destination. Additionally, this study will determine the interrelationships between the factors affecting tourist motivation by proposed the research framework for the future study.

\section{Literature Review}

Relaxation and relief, health and beauty, escape, self-development and tourist motivation

Wellness refers to being in a lifestyle arranged towards ideal health and wellbeing in which the body, mind, and spirit are incorporated by the person to live entirely within the human and universal group, (Myers, Sweeney \& Witmer, 2005). On account of Hong Kong Spa Goers, Athena \& Mak (2009) contents that factors such as (relaxation and relief, health and beauty, escape) create the intention to visit spa and wellness Centers. While Konu \& Laukkanen (2009) in a Finnish case proves, that selfdevelopment serves as one of the prime intentions to make wellbeing holidays. Visualizing a different behavior among global spa-goers, this study, therefore, intends to identify the factors that motivate the tourist in visiting the spa and wellness centers in the context of Malaysian spa-goers specifically at Kuala Lumpur.

\section{Tourist Motivation}

Motivation is the essential perspective that empowers an individual or vacationers to engage in certain activities with full commitment. Tourist motivation can be described as the mental ability to decide the longing to travel (Mahika, 2011). Chan, Yap, \& Chet, (2012) supports that ASEAN countries such as Malaysia, Thailand, and Singapore have utmost potential to become the best tourism hubs based on forecasted medical tourist arrival. Maslow's (1970) hierarchy of needs convinced to be an essential theory used in studying tourist motivation and it comprises five levels of needs explicitly physiological, safety, love/belongings, esteem, and self-actualisations. Vacationers and spa visitors have the distinctive desire of likely experience and outcome that they were seeking and /or will endure, (Adam, 2003). SRI International (2010) cited that health and wellness goods and services seemed to be the prime motivation among spa-goers based on past consumer research.

\section{Relaxation, Relief, and Tourist Motivation}

Relaxation and relief commonly refer to seeking mental peacefulness, seeking physical relaxation, seeking spiritual refreshments and to seek relief for a medical condition and it serves as the primary factor that creates the intention to visit spa and wellness centers (Athena \& Mak, 2009). The status of a person who is carrying on with a furious life will look for the need of unwinding and relief due to 
INTERNATIONAL JOURNAL OF ACADEMIC RESEARCH IN BUSINESS AND SOCIAL SCIENCES Vol. 9, No. 5, May, 2019, E-ISSN: 2222-6990 @ 2019 HRMARS

the pressure of workloads and mental aggravation. Maslow's (1970) supported that this factor is the fundamental physiological needs to be fulfilled before seeking higher order needs. People want to be distressed, decompressed, secured and cared for (McNeil \& Ragins, 2005) and American hotels remodelled their amenities by including Spa to pamper their guests (Azman \& Chan, 2010).

Preposition 1: Relaxation and relief is positively related to tourist motivation

\section{Health and Beauty}

Health and beauty refer to those spa visitors who consider improving overall health, enhance physical attractiveness, rejuvenate one's appearance and lose weight, (Athena \& Mak, 2009). Ford (2008) argues that Yoga and Pilates practices provide extraordinary services to lose weight, lower cholesterol and achieve overall wellbeing. Individuals also perceive it as fundamental for reputations among companions and relatives', thus rejuvenating is necessary. Ban, \& Olimpia (2007) emphasised on the current trend of choosing a holiday that vacationers elect for health and beauty holidays and intellectually active holidays. Similarly, the rise in the demand for elective and cosmetic surgery among Asian regions is reported by (Chan, Yap \& Chet, 2012).

\section{Preposition 2: Health and beauty is positively related to tourist motivation}

\section{Escape}

Escape can be depicted as a state where an individual needed to make tracks in the opposite direction from the weight of work, routines, and social lives. Athena \& Mak, (2009) proves that Hong Kong spagoers often seek to escape to tranquil environments due to pressure and unreasonable overstimulation and it is a factor initiated with tourist motivations (Pearce \& Lee, 2005). Yoon \& Uysal, (2005) cited that push motivation such as escape has a direct positive effect on behavioral intentions of tourists. Holden (2006) asserts that the motivation of tourist lies within behavioral organisations and standards of civilisation, which could be related to escapism. Escapism could be related to (Kaulbars, 2009) who illuminates travel behavior that observes leisure as disruption from day-to-day.

Preposition 3: Escape is positively related to tourist motivation

\section{Self-development}

Self-development is recognized as a factor that creates the intention among European tourist to make wellbeing holidays. Konu \& Laukkanen, (2009) supports that it comprises a few contributing elements such as experiencing different cultures, experiencing something contrast and aesthetic, nurturing self-understanding, developing skills and abilities. Pearce \& Lee, (2005) argued that self-development could be divided into two aspects namely host- site involvement and personal development. Hostsite involvement includes learning new things, experiencing different cultures, developing an area of knowledge, meeting and observing locals and following the current event. Meanwhile, personal development includes developing personal interest, knowing capabilities, gain a sense of accomplishment and self-confidence and pursuing skills and talents. It fundamentally covers reconciliation and development of body, mind, and spirit (Smith \& Kelly, 2006), while it can also be 
INTERNATIONAL JOURNAL OF ACADEMIC RESEARCH IN BUSINESS AND SOCIAL SCIENCES

Vol. 9, No. 5, May, 2019, E-ISSN: 2222-6990 @ 2019 HRMARS

aligned with the understanding of spirituality which aims to develop beyond the self and ego. In short, five questions are posted which also related to the problem statement of this proposed study:

\section{Preposition 4: Self-development is positively related to tourist motivation}

\section{Proposed Research Framework}

Based on the previous literature, this paper proposes a comprehensive approach to address the relationship between relaxation and relief, health and beauty, escape and self-development as the factors that motived tourist to choose their tourism destination. It is proposed that there is positive relationship between these variables. Moreover, prior studies show that the number of spa and wellness center increases and the practice towards healthier lifestyle were accepted worldwide. While many studies have been executed in this area, researches are found to be fragmented in their approach. The overall proposed framework for tourist motivation is shown in Figure 1.

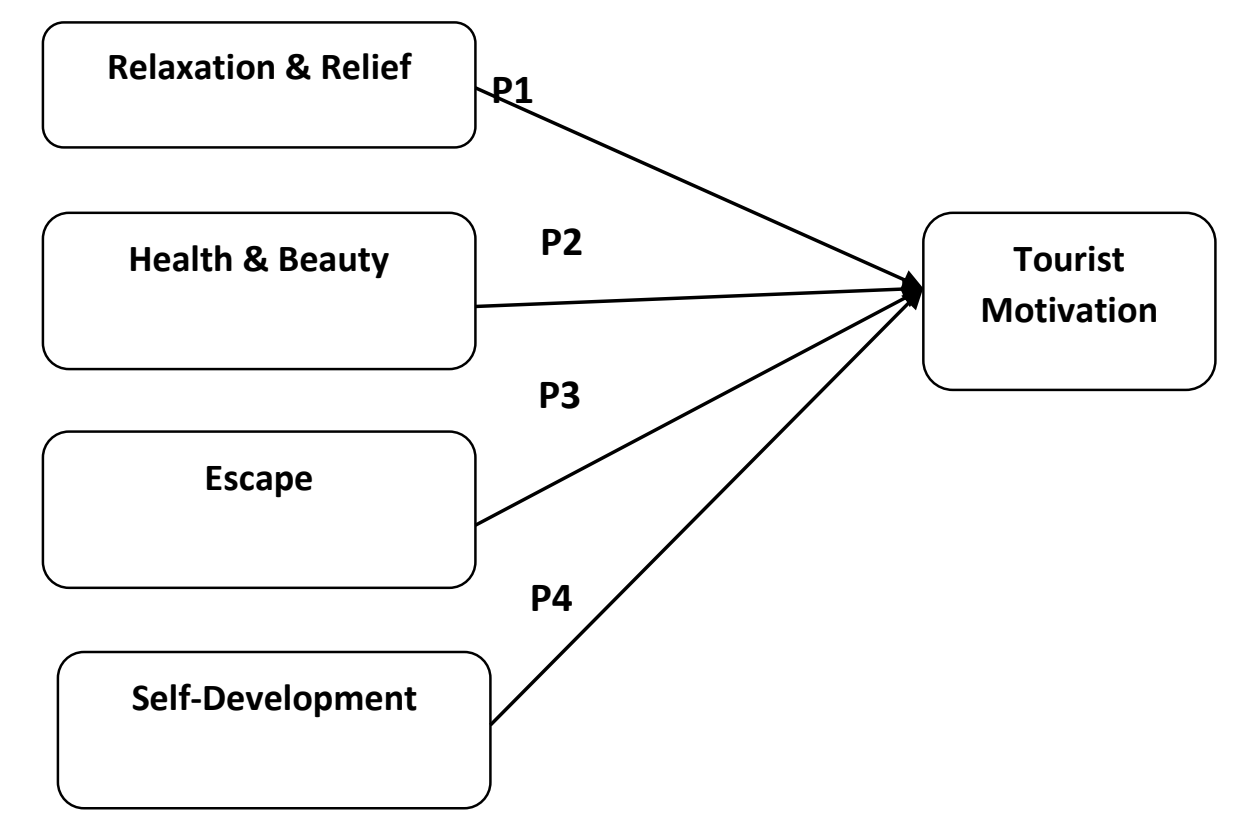

\section{Conclusion}

It is believed that this study will be able to fill the gap in the literature by focusing on the motivation of tourist to visit the Spa and wellness centre. In addition, there is a need for researchers in tourism studies to expand more understanding on the attributes of the tourist motivation that needed as the new market strategies and market segmentation in the tourism and hospitality industry in the future. From the practical perspective, this study will supporting document for the Ministry of Tourism and Culture of Malaysia in promoting the Spa industry in Malaysia. Furthermore, this study expected to give benefit the SPA industry players such as Malaysian association of wellness and spa (MAWSPA), Global Spa \& Wellness Summit (GSWS), and the hotel industry to develop a proper strategy on marketing and improve their service to meet up the tourist needs and wants. It will also give 
INTERNATIONAL JOURNAL OF ACADEMIC RESEARCH IN BUSINESS AND SOCIAL SCIENCES

Vol. 9, No. 5, May, 2019, E-ISSN: 2222-6990 @ 2019 HRMARS

advantages to the SPA centre's itself and help them to be competitive and improve based on the tourist expectations.

\section{Acknowledgement}

This research did not receive any specific grant from funding agencies in the public, commercial, or not-for-profit sectors.

\section{Corresponding Author}

Nik Alif Amri Bin Nik Hashim, Faculty of Hospitality, Tourism and Wellness, Universiti Malaysia

Kelantan, Malaysia,

Email: nikalifamri@gmail.com

\section{References}

Adams, T. B. (2003). The Power of Perceptions: Measuring Wellness in a Globally Acceptable, Philosophically Consistent Way. Wellness Management.

Athena, H. N \& Mak, K. K. (2009). Health or Self-Indulgence? The Motivation and Characteristic among Spa Goers. International Journal of Tourism Research, 185-199.

Azman, I., \& Chan, J. (2010). Health and Spa Tourism Business: Tourists' profiles and motivational factors. In Proceedings of the Travel and Tourism Research Association Europe 2010 Annual Conference 9-25. Dalarna, Sweden: Travel and Tourism Research Association Europe.

Olimpia, B. (2007), Tehnici promotionale si specificul lor in turism, Ed. Economica,

Chan, D. K., Yap,K. \& Chet, Y. C. (2012). A “:Blue Ocean” for Malaysia'sMedical and Tourism Industry. Malaysia, Thailand. 1-12

Ford, M. C. (2008). Fitness and Wellness. San Francisco/Boston.

Global Wellness Summit. (2016). Summit Mission. Retrieved august 04, 2016, from GLOBAL WELLNESS SUMMIT. Retrieved from http://www.globalwellnesssummit.com

Konu, H. \& Laukkanen, T. (2009). Roles of Motivation factors in predicting the tourist's intention to make Wellbeing Holidays - a Finnish case. ANZMAC , 1-9

Holden, A. (2006). 'Tourism Studies and the Social Sciences'. Abingdon: Routledge.

Kaulbars, J. (2009), Escape - The Real Motivation for Leisure Travel, Munich, GRIN Verlag, From http://www.grin.com/en/e-book/231143/escape-the-real-motivation-for-leisure-travel

Mahika, E. C. (2011). Current trends in Tourist Motivation. Cactus Tourism Journal, 2(2), 15 - 24.

Maslow A. (1970). Motivation and Personality. Harper and Row: New York.

McNeil, K. R., \& Ragins, E. J. (2005). Staying in the Spa Marketing Game: Trends, Challenges, Strategies, and Techniques. Journal of Vacation Marketing, 11(31), 31- 39.

Smith, M. \& Kelly, C. (2006). Wellness Tourism. Tourism Recreation Research , 31(1) 1-4.

Smith, M., Macleod, N. \& Robertson, M. H. (2010). Key Concepts in Tourist Studies. London: SAGE Publication Ltd.

Myers, J. E., Sweeney, T. J. \& Witmer, M. (2005). A Holistic Model of Wellness. Retrieved from http://www.mindgarden.com/products/wells.htm

Pearce, P. L. \& Lee, U. (2005). Developing the Travel Career Approach to Tourist Motivation. Journal of Travel Research, 43, 226-237. 
Sekaran, U. \& Bougie, R. (2016). Research Methods for Business: A Skill Building Approach. United Kingdom: John Wiley \& Sons, Ltd, Publication.

SRI International (2010), Global Spa Summit, Spas and the Global Wellness Market: Synergies and Opportunities

Yoon, Y. \& Uysa, I. M. (2005). An examination of the Effects of Motivation and Satisfaction on Destination Loyalty: A structural model. Tourism Management,26 , 45-56. 